\title{
ENTRE UM SISTEMA ELEITORAL DISPERSIVO E UM REGRAMENTO PARLAMENTAR CONCENTRADOR: O COMPORTAMENTO DOS DEPUTADOS FEDERAIS
}

\section{RESUMO}

ESTE TRABALHO PROCURA COMBINAR UMA EXPLICAÇĀO DA AC̣ÃO DOS DEPUTADOS FEDERAIS DA 53ª LEGISLATURA (2007-2011), A PARTIR DE ELEMENTOS ESTRUTURAIS, SOBRETUDO AS CONSTRIC̄ÕES E AS POTENCIALIDADES OBJETIVAS INSCRITAS NAS ESTRUTURAS PARTIDÁRIAS, COM UMA COMPREENSĀO DAS REPRESENTAC̣̃̃ES QUE ESSES PARLAMENTARES FAZEM DA PRÓPRIA CONDUTA. NO CURSO DESSE PROCESSO, BUSCA EXPLICAR/ COMPREENDER A INFLUÊNCIA DA COMBINAÇĀO PRESIDENCIALISMO/ REPRESENTAÇÃO PROPORCIONAL COM LISTA ABERTA, DE UM LADO, E DA COMBINAÇĀO DE PODER DE AGENDA DO PRESIDENTE DA REPÚBLICA/ CENTRALIZAC̣ÃO DOS TRABALHOS DA CÂMARA DOS DEPUTADOS NAS MÃOS DOS LÍDERES PARTIDÁRIOS, DE OUTRO, SOBRE O COMPORTAMENTO PARLAMENTAR, ASSIM COMO AS ACÕESS DOS DEPUTADOS TENDENTES A REPRODUZIR OU TRANSFORMAR ESSE ESTADO DE COISAS. CONCLUI QUE AS REGRAS POLÍTICAS VIGENTES NO BRASIL TÊM CONCORRIDO PARA A FORMAÇÃO DE UMA MULTIPLICIDADE DE PARTIDOS POLÍTICOS FRACOS, COM POUCA CAPILARIDADE SOCIAL, IDENTIDADE IDEOLÓGICO-PROGRAMÁTICA E COESĀO, CONSISTINDO DE POLÍTICOS INDIVIDUALISTAS, PARTICULARISTAS, PERSONALISTAS E APARTIDÁRIOS, BEM COMO DE LIDERANÇAS PARLAMENTARES QUE NÃO CONSEGUEM INFLUENCIAR, DE MODO DECISIVO, O COMPORTAMENTO DAS RESPECTIVAS BANCADAS. EM COMPENSAC̣ÃO, O GOVERNO TEM OCUPADO TODOS OS VAZIOS DE PODER QUE OS PARTIDOS E AS LIDERANÇAS PARTIDÁRIAS

\author{
Júlio Roberto de Souza Pinto
}

BETWEEN A DISPERSING ELECTORAL SYSTEM AND CENTRALIZING PARLIAMENTARY RULES: THE BEHAVIOR OF BRAZILIAN FEDERAL REPRESENTATIVES

\section{ABSTRACT}

THIS STUDY SEEKS TO COMBINE AN EXPLANATION OF THE ACTIONS OF THE MEMBERS OF THE BRAZILIAN CHAMBER OF DEPUTIES DURING THE 2007-2011 LEGISLATIVE TERM, TAKING INTO ACCOUNT STRUCTURAL ELEMENTS, PARTICULARLY THE OBJECTIVE CONSTRICTIONS AND POTENTIALITIES UNDERLYING THE PARTY STRUCTURES, WITH AN INTERPRETATIVE UNDERSTANDING OF THE REPRESENTATIONS THE DEPUTIES MAKE OF THEIR OWN CONDUCT. IN THE COURSE OF THIS PROCESS, IT SEEKS TO EXPLAIN/UNDERSTAND THE INFLUENCE THAT THE COMBINATION PRESIDENTIAL SYSTEM/OPEN-LIST PROPORTIONAL REPRESENTATION, ON THE ONE HAND, AND THE COMBINATION PRESIDENT'S CONTROL OF THE POLITICAL AGENDA/CHAMBER OF DEPUTIES' CENTRALIZED STRUCTURE, ON THE OTHER HAND, EXERT ON PARLIAMENTARY BEHAVIOR, AS WELL AS THE ACTIONS OF THE DEPUTIES INTENDED TO REPRODUCE OR TRANSFORM THIS STATE OF AFFAIRS. IT CONCLUDES THAT THE EXISTING POLITICAL RULES IN BRAZIL HAVE CONTRIBUTED TO THE FORMATION OF A MULTIPLICITY OF WEAK POLITICAL PARTIES, WITH LITTLE SOCIAL CAPILLARITY, IDEOLOGICAL-PROGRAMMATIC IDENTITY AND COHESION, CONSISTING OF INDIVIDUALISTIC, PARTICULARISTIC, PERSONALISTIC, AND NON-PARTISAN POLITICIANS, AS WELL AS OF PARLIAMENTARY LEADERS WHO CANNOT INFLUENCE, DECISIVELY, THE BEHAVIOR OF THEIR OWN BENCHES. IN RETURN, THE EXECUTIVE BRANCH OF THE GOVERNMENT HAS OCCUPIED ALL THE GAPS OF POWER THAT PARTIES AND PARTY LEADERS HAVE BEEN UNABLE TO FILL 
NÃO TÊM SIDO CAPAZES DE PREENCHER NAS ESTRUTURAS DA CÂMARA dOS DEPUTAdOS. VALENDO-SE dOS PODEROSOS RECURSOS POSTOS A SUA DISPOSIÇÃO, O GOVERNO TEM DEFINIDO A CONFIGURAÇÃO DO TABULEIRO POLÍTICO DA CÂMARA, NĀO SOMENTE COOPTANDO DEPUTADOS DA OPOSIÇÃO, MAS TAMBÉM DETERMINANDO A ESCOLHA E A MANUTENÇÃO DOS LÍDERES DAS BANCADAS PARTIDÁRIAS QUE INTEGRAM SUA BASE DE SUSTENTAÇÃO. A ANÁLISE COMPARADA DAS ÚLTIMAS TENTATIVAS DE REFORMA DO SISTEMA ELEITORAL-PARTIDÁRIO, DE UMA BANDA, E DE LIMITACĀO DOS PODERES DE AGENDA DO PRESIDENTE, DE OUTRA, DEIXA CLARO QUE O GOVERNO É A GRANDE FORÇA MOBILIZADORA DAS ESTRUTURAS EXISTENTES NA CÂMARA DOS DEPUTADOS.

\section{PALAVRAS-CHAVE}

AÇÃO PARLAMENTAR; ESTRUTURA PARTIDÁRIA; REFORMA POLÍTICA; LIMITAÇÃO DOS PODERES LEGISLATIVOS DO PRESIDENTE DA REPÚBLICA.

\begin{abstract}
IN THE STRUCTURES OF THE CHAMBER OF DEPUTIES. TAKING THE ADVANTAGE OF POWERFUL RESOURCES PUT AT ITS DISPOSAL, THE EXECUTIVE BRANCH OF THE GOVERNMENT HAS DEFINED THE CONFIGURATION OF THE POLITICAL CHESSBOARD OF THE CHAMBER, NOT ONLY CO-OPTING OPPOSITION DEPUTIES BUT ALSO DETERMINING THE CHOICE AND MAINTENANCE OF THE LEADERS OF PARTY GROUPS WHO MAKE UP ITS SUPPORT BASE. COMPARATIVE ANALYSIS OF RECENT ATTEMPTS TO REFORM THE ELECTORAL-PARTISAN SYSTEM, ON THE ONE SIDE, AND TO LIMIT THE PRESIDENT'S CONTROL OF THE POLITICAL AGENDA, ON THE OTHER SIDE, MAKES CLEAR THAT THE EXECUTIVE BRANCH OF THE GOVERNMENT IS THE GREAT MOBILIZING POWER OF EXISTING STRUCTURES IN THE CHAMBER OF DEPUTIES.
\end{abstract}

\section{KEYWORDS}

PARLIAMENTARY ACTION; PARTY STRUCTURE; POLITICAL REFORM; LIMITATION OF LEGISLATIVE POWERS OF THE PRESIDENT.

\section{INTRODUÇÃO}

A maioria dos estudos sobre a ação dos deputados federais brasileiros tem procurado explicar a atuação desses parlamentares objetivamente, a partir de elementos estruturais.

Estudiosos como Scott Mainwaring (1993) buscam explicar o comportamento parlamentar a partir de elementos ditos "constitucionais", dentre os quais se destacam os sistemas de governo e os sistemas eleitoral-partidários.

Mainwaring entende que a combinação de presidencialismo com proporcionalismo e multipartidarismo estimularia o radicalismo, a indisciplina partidária e o distanciamento da vontade do eleitor na ação parlamentar.

Os sistemas proporcionais e o multipartidarismo deles decorrente facilitariam a entrada de políticos radicais. Essa polarização ideológica tenderia a ser menor nos sistemas majoritários ou bipartidários, devido às elevadas barreiras de entrada e à necessidade de ganhar os votos do centro, características supostamente inerentes a esses sistemas.

Afora isso, sustenta Mainwaring, os parlamentares tenderiam a agir de forma indisciplinada em sistemas que combinam presidencialismo com proporcionalismo e multipartidarismo, na medida em que nesses sistemas as coalizões interpartidárias seriam construídas e mantidas de forma sempre precária. Uma vez que os ministros são escolhidos pelos presidentes sem a participação efetiva dos partidos, os integrantes destes últimos não estariam firmemente comprometidos a apoiar o governo. Nem mesmo quando seus partidos detêm ministérios, os parlamentares estariam comprometidos a sustentar o governo em uma base permanente, não sendo infrequente que governos mantenham em ministérios membros de partidos apenas para fazer frente à oposição, no parlamento, de grande parte desses mesmos partidos. 
Por último, a responsabilização ou a accountability eleitoral seria dificultada nas combinações de presidencialismo com proporcionalismo e multipartidarismo, dificuldade agravada nos casos de fraca institucionalização dos partidos. De acordo com Mainwaring e Torcal (2005), nos sistemas partidários fluidos, o personalismo, desprovido de componentes ideológicos, programáticos ou de identificação partidária, exerceria maior influência na hora do voto. Ou seja, muitos eleitores seriam influenciados mais pela personalidade do que pelo partido, políticos antipartidos teriam mais chance de ganhar eleições, bem como o populismo e a antipolítica seriam mais comuns, tudo isso concorrendo para uma atuação parlamentar menos comprometida com a vontade dos eleitores.

Outros estudiosos como Argelina Figueiredo e Fernando Limongi (1999) procuram explicar a ação dos deputados federais levando em consideração a inter-relação entre tais elementos constitucionais e os chamados "procedimentais", mantendo, porém, a mesma perspectiva objetivista.

Figueiredo e Limongi sustentam que, se em alguns países "elementos constitucionais" como a combinação de presidencialismo com proporcionalismo e multipartidarismo têm estimulado o radicalismo, a indisciplina partidária e o distanciamento da vontade dos eleitores na ação parlamentar, tais efeitos, sobretudo no que toca à indisciplina, no Brasil seriam atenuados e algumas vezes até anulados por "elementos procedimentais" como o forte poder de agenda do presidente da República e a alta centralização dos trabalhos parlamentares nas mãos dos líderes partidários.

De um lado, a Constituição de 1988 teria mantido os instrumentos introduzidos pelos militares com vistas a garantir a preponderância do Executivo sobre o Legislativo e uma maior presteza por parte deste último na consideração das proposições do primeiro, tais como a iniciativa exclusiva de certas leis, a atribuição de urgência pelo presidente da República a projetos de sua autoria e a edição pelo chefe do Executivo de medidas provisórias com força de lei. De outro lado, os recursos legislativos colocados à disposição dos líderes partidários teriam sido ampliados pelos novos regimentos internos das casas legislativas. Tudo isso concorreria para uma atuação parlamentar mais disciplinada e cooperativa. Em outras palavras, os deputados federais não encontrariam um arcabouço institucional próprio para perseguir interesses particularistas. Ao contrário, a melhor estratégia para a obtenção de recursos visando a retornos eleitorais seria votar com a bancada (FIGUEIREDO; LIMONGI, 1999).

Ainda outros estudiosos como Barry Ames (2000), conquanto mantenham o enfoque objetivista, buscam explicar a ação dos deputados federais levando em conta outros elementos. Na avaliação de Ames, o fato de deputados de um mesmo partido votarem juntos não prova que a influência entre líderes e liderados flui de cima para baixo. Ao contrário, esse fenômeno poderia demonstrar a ocorrência de um processo de barganha bem-sucedido, em que quase todos os deputados estariam satisfeitos com seu ganho individual. De qualquer modo, a análise das votações nominais somente se 
prestaria para medir a força das lideranças partidárias dentro de um modelo multivariado. Ou seja, para se fazerem inferências sobre a força dos líderes das bancadas partidárias, seria preciso avaliar a importância de outros determinantes de votação partidária, incluindo-se entre eles as ideologias, as características do eleitorado, os benefícios decorrentes de pork-barre $1^{1}$ e o tempo de permanência no cargo.

São raros, entretanto, os estudos que procuram combinar uma explicação da ação dos deputados federais a partir de elementos estruturais, de um lado, com uma compreensão do sentido que os próprios atores atribuem a sua conduta, de outro. A maioria atem-se apenas a generalizações explicativas ou a processos e circunstâncias que se desenrolam "nas costas" desses agentes, desprezando as generalizações cognitivamente sustentadas, explícita ou tacitamente, por esses atores e recorrentemente mobilizadas na produção cotidiana de suas condutas.

Este trabalho, todavia, empregando uma metodologia construída sobre formulações feitas por Jürgen Habermas (1988 [1967]), Pierre Bourdieu (2001) e Anthony Giddens (1986 [1984]), ${ }^{2}$ busca explicar a ação dos deputados federais da $53^{\text {a }}$ Legislatura (2007-2011), particularmente em sua relação com a estrutura partidária, a partir das restrições e das habilitações objetivas inscritas em seu posicionamento nessa estrutura em particular e na estrutura da Câmara em geral, ao mesmo tempo que busca compreender a representação que esses parlamentares podiam fazer do posicionamento deles próprios e de seus correligionários e adversários, em função das informações que detinham e de suas estruturas cognitivas, ao pressuposto de que essa representação era elemento constitutivo de sua conduta.

No curso desse processo explicativo-compreensivo do comportamento parlamentar, procuraram-se respostas às seguintes questões: (1) Como o sistema eleitoral-partidário, notadamente o sistema proporcional de lista aberta, combinado com o sistema presidencialista de governo, influenciava a ação dos deputados federais na $53^{\text {a }}$ Legislatura (2007-2011), particularmente em sua relação com a estrutura partidária? (2) Como o poder de agenda do presidente da República, combinado com a centralização das atividades da Câmara dos Deputados nas mãos dos líderes partidários, confluía com aqueles elementos ditos "constitucionais" em tal comportamento parlamentar? (3) Como os deputados, por sua vez, agiam para reproduzir ou transformar esse estado de coisas?

No esforço de explicar/compreender a ação dos deputados federais na $53^{\text {a }}$ Legislatura, procurou-se, inicialmente, identificar as estruturas partidárias então existentes na Câmara e os parlamentares a elas relacionados, bem como definir o grau de institucionalização dessas estruturas ou de padronização de condutas e práticas em seu interior, como os deputados se posicionavam em tais estruturas, o capital específico que esses parlamentares aportavam e as relações de força instauradas. O critério utilizado na identificação das estruturas partidárias foi o estabelecido pelo Supremo Tribunal Federal (STF) na Ação Direta de Inconstitucionalidade n. 1.351, em 2006, e no 
Mandado de Segurança n. 26.460, em 2007: têm direito a funcionamento parlamentar e, por conseguinte, fazem jus a representação e liderança os partidos que tenham elegido para a Câmara dos Deputados e ali mantenham filiados representantes de pelo menos três diferentes estados.

Nessa primeira fase, procedeu-se ao levantamento de dados junto à SecretariaGeral da Mesa e às Lideranças Partidárias da Câmara dos Deputados, à observação de interações no interior das estruturas partidárias em particular e da Câmara em geral e à entrevista semiestruturada, primeiro de assessores das Lideranças Partidárias e depois de deputados. As interações observadas e os assessores entrevistados foram selecionados a partir da construção de um sistema de rede, em que se buscaram, entre os servidores da Câmara, "egos focais" que dispusessem de informações úteis ao mapeamento das estruturas e à decodificação de suas regras. A identidade dos assessores entrevistados foi preservada. ${ }^{3}$ Os deputados entrevistados foram selecionados entre aqueles que se tinham destacado nos processos analisados, seja por haverem sido autores de proposições, emendas e questões de ordem, seja por terem participado de discussões e encaminhamentos de matérias, seja por haverem votado contra a orientação do líder.

As estruturas partidárias - dezessete de acordo com o critério estabelecido pelo STF - estão ordenadas segundo seu posicionamento no espectro ideológico clássico e seu posicionamento em relação ao governo. Na análise de cada uma dessas dezessete estruturas partidárias então existentes na Câmara, deu-se especial atenção à origem dos partidos, ao posicionamento do partido e da bancada no espectro ideológico clássico, às migrações partidárias, à relação das bancadas com os líderes parlamentares e com os dirigentes partidários, à pretensão do partido de governar o país e ao posicionamento do partido e da bancada em relação ao governo.

As ações parlamentares analisadas foram as proposições (propostas de emendas à Constituição - PECs, projetos de lei complementar - PLPs, projetos de lei - PLs, projetos de resolução - PRCs, emendas e pareceres), os pronunciamentos (justificações de proposições, discussões no Plenário e encaminhamentos de votações), as votações nominais e as questões de ordem relacionados ao sistema eleitoral-partidário e à concentração de poderes legislativos nas mãos do presidente da República e dos líderes da Câmara dos Deputados. Em outras palavras, o exame da influência da combinação de presidencialismo com proporcionalismo de lista aberta e outros aspectos do sistema eleitoral-partidário, em inter-relação com a combinação de poder de agenda do presidente com concentração dos trabalhos da Câmara nas mãos dos líderes, sobre o comportamento dos deputados, teve como locus privilegiado as ações mesmas desses parlamentares tendentes a reproduzir ou transformar tal situação.

Na primeira parte dessa última fase do trabalho, a parte explicativa, procedeu-se à análise de documentos obtidos junto à Secretaria-Geral da Mesa da Câmara dos Deputados: fichas de tramitação das proposições; inteiro teor das proposições principais e 
das apensadas, das emendas e dos substitutivos; notas taquigráficas dos pronunciamentos nas discussões e nos encaminhamentos das votações. Somente foram preliminarmente examinadas as proposições que tinham sido objeto de parecer. Entre essas proposições, deu-se especial destaque ao PL n. 1.210/2007 - reforma política - e à PEC n. 511/2006 - medidas provisórias -, seja pelo interesse que despertaram nos deputados dos diferentes partidos, ideologias e regiões do país - interesse demonstrado na intensa participação desses parlamentares na forma de emendas, pronunciamentos e questões de ordem -, seja por sua ampla repercussão na sociedade.

Na segunda parte, a parte compreensiva, procedeu-se à análise dos discursos consubstanciados nas justificações das proposições e nos pronunciamentos no Plenário, e à entrevista semiestruturada dos deputados que tiveram atuação destacada nos processos de apreciação do PL n. 1.210/2007 e da PEC n. 511/2006.

$\mathrm{Na}$ análise do comportamento parlamentar, tanto num como noutro processo legislativo, enfocou-se especialmente a coesão interna e a articulação entre si das várias bancadas partidárias.

\section{Estrutura PARTIDÁRIA}

$\mathrm{Na} 53^{\mathrm{a}}$ Legislatura (2007-2011), dezessete partidos políticos tinham funcionamento e, consequentemente, detinham direito a representação e liderança na Câmara dos Deputados. Na Tabela 1, esses partidos estão classificados de acordo com seu posicionamento no espectro ideológico clássico e seu posicionamento em relação ao governo. Essa classificação, porém, não era pacífica, pois as ações dos partidos nem sempre guardavam coerência com as declarações ideológicas contidas em seus estatutos e seu posicionamento em relação ao governo nem sempre era formalizado no âmbito da Câmara. A evidência mais eloquente dessa falta de coerência ideológica era o fato de vários partidos declaradamente de direita ou centro-direita haverem integrado a base parlamentar de sustentação do governo Luís Inácio Lula da Silva, declaradamente de esquerda ou centro-esquerda. Já a situação do Partido Socialismo e Liberdade (PSOL) era bem emblemática da ambiguidade que cercava a relação de alguns partidos com o governo ou com a oposição: ainda que mais alinhado ideologicamente com partidos como o Partido dos Trabalhadores (PT), frequentemente acompanhava o Partido Popular Socialista (PPS), o Partido da Social Democracia Brasileira (PSDB) e o Democratas (DEM) em sua oposição ao governo. O próprio PPS não tinha muita afinidade ideológica com o DEM. ${ }^{4}$ 
tabela 1 - Partidos Com funcionamento na CÂmara dos Deputados NA $53^{\text {a }}$ LEGISLATURA (2007-20II), CLASSIFICADOS DE ACORDO COM SEU POSICIONAMENTO NO ESPECTRO IDEOLÓGICO CLÁSSICO E COM SEU POSICIONAMENTO EM RELAÇÃO AO GOVERNO

\begin{tabular}{llll} 
& ESQUERDA OU CENTRO-ESQUERDA & CENTRO & CENTRO-DIREITA OU DIREITA \\
\hline GOVERNO & PCDOB, PDT, PSB, PT, PV & PMDB, PMN & PP, PR, PRB, PSC, PTB, PTC \\
\hline OPOSIC̣ÃO & PPS, PSOL ${ }^{5}$ & PSDB & DEM \\
\hline
\end{tabular}

Fontes: Secretaria-Geral da Mesa da Câmara dos Deputados e Supremo Tribunal Federal (Ação Direta de Inconstitucionalidade n. 1.351, de 2006, e Mandado de Segurança n. 26.460, de 2007).

Alguns desses partidos formavam blocos parlamentares. $\mathrm{Na} 53^{\mathrm{a}}$ Legislatura, havia na Câmara dos Deputados dois blocos parlamentares: o bloco formado pelo Partido do Movimento Democrático Brasileiro (PMDB) e pelo Partido Trabalhista Cristão (PTC); e o bloco formado pelo Partido Socialista Brasileiro (PSB), pelo Partido Comunista do Brasil (PCdoB), pelo Partido da Mobilização Nacional (PMN) e pelo Partido Republicano Brasileiro (PRB).

A Tabela 2 resume os dados produzidos sobre as estruturas partidárias existentes no interior da Câmara dos Deputados na 53ª Legislatura (2007-2011). ${ }^{6}$

TABELA 2 - RESUMO COMPARATIVO DAS ESTRUTURAS PARTIDÁRIAS CÂMARA dOS DePUTAdos - $53^{\mathrm{a}}$ Legislatura (2007-20I I)

\begin{tabular}{|c|c|c|c|c|c|c|c|c|c|c|c|c|c|c|c|c|c|}
\hline & PCDoB & PDT & PSB & PT & PV & PPS & PSOL & PMDB & PMN & PSDB & PP & PR & PRB & PSC & РTB & PTC & DEM \\
\hline DEPUTADOS & 12 & 23 & 27 & 77 & 15 & 14 & 3 & 89 & 3 & 57 & 40 & 44 & 7 & 16 & 23 & 3 & 55 \\
\hline $\begin{array}{l}\text { VOTOS DE } \\
\text { LEGENDA }\end{array}$ & $92 \%$ & $100 \%$ & $89 \%$ & $100 \%$ & $93 \%$ & $100 \%$ & $100 \%$ & $93 \%$ & $100 \%$ & $93 \%$ & $90 \%$ & $95 \%$ & $100 \%$ & $94 \%$ & $96 \%$ & $100 \%$ & $95 \%$ \\
\hline $\begin{array}{r}\text { MUDANÇA } \\
\text { DE PARTIDO }\end{array}$ & $0 \%$ & $13 \%$ & $11 \%$ & $1 \%$ & $20 \%$ & $7 \%$ & $0 \%$ & $9 \%$ & $0 \%$ & $7 \%$ & $7 \%$ & $52 \%$ & $85 \%$ & $44 \%$ & $13 \%$ & $33 \%$ & $0 \%$ \\
\hline $\begin{array}{r}\text { PERDA PARA } \\
\text { OUTROS } \\
\text { PARTIDOS }\end{array}$ & $0 \%$ & $17 \%$ & $18 \%$ & $4 \%$ & $8 \%$ & $41 \%$ & $0 \%$ & $11 \%$ & $67 \%$ & $12 \%$ & $2 \%$ & $12 \%$ & $0 \%$ & $11 \%$ & $0 \%$ & $33 \%$ & $21 \%$ \\
\hline
\end{tabular}


Levando-se em conta que a média do tamanho das bancadas na Câmara na $53^{\mathrm{a}}$ Legislatura (2007-2011) era de 29,88 deputados, pode-se dizer que apenas seis dos dezessete partidos políticos com funcionamento na Câmara dos Deputados estavam acima da média, dos quais apenas um era de esquerda ou centro-esquerda (PT), dois eram de centro (PMDB e PSDB) e três eram de centro-direita ou direita (Partido Progressista - PP, Partido da República - PR e DEM). Essas seis maiores bancadas partidárias, no entanto, correspondiam a 71\% da composição da Câmara. As bancadas de esquerda ou centro-esquerda (do PCdoB, do Partido Democrático Trabalhista - PDT, do PSB, do PT, do Partido Verde - PV, do PPS e do PSOL) correspondiam a 34\% da composição da Câmara, as bancadas de centro (do PMDB, do PMN e do PSDB) a 29\% e as bancadas de centro-direita e direita (do PP, do PR, do PRB, do Partido Social Cristão - PSC, do Partido Trabalhista Brasileiro - PTB, do PTC e do DEM) a 37\%. Ou seja, a composição da Câmara dos Deputados naquela legislatura era predominantemente de centro-direita ou direita. As bancadas partidárias que integravam a base de sustentação do governo Lula (do PCdoB, do PDT, do PSB, do PT, do PV, do PMDB, do PMN, do PP, do PR, do PRB, do PSC, do PTB e do PTC), por sua vez, correspondiam a 75\% da composição da Câmara. Apenas 40\% dessa base eram de esquerda ou centro-esquerda. Além disso, vale destacar o alto número e a elevada diversidade ideológica das bancadas partidárias que compunham a base governista.

Apenas as bancadas do PDT, do PT, do PPS, do PSOL (esquerda ou centroesquerda), do PMN (centro), do PRB e do PTC (centro-direita ou direita) tinham sido inteiramente eleitas pelos votos de legenda. Ou seja, entre os deputados eleitos pelos votos de legenda, prevaleciam os integrantes das bancadas de esquerda ou centro-esquerda. Entretanto, a bancada em que se achava o maior número relativo de deputados eleitos pelos votos próprios era a do PSB, partido de esquerda ou centro-esquerda sucessivamente controlado por personalidades como Miguel Arraes e Anthony Garotinho.

As bancadas partidárias com os maiores números relativos de deputados eleitos por outras legendas e que, portanto, registravam as maiores porcentagens de mudança de partido eram as do PDT, do PSB e do PV (esquerda ou centro-esquerda), do PR, do PRB, do PSC, do PTB e do PTC (centro-direita ou direita), todas governistas. Em outras palavras, as bancadas governistas eram as que mais tinham recebido deputados de outras bancadas partidárias, com destaque para as bancadas de centro-direita ou direita. Mais da metade dos integrantes da bancada do PR e três quartos da bancada do PRB eram oriundos de outras bancadas partidárias.

Entre as bancadas partidárias com as maiores perdas relativas de deputados para outras legendas, encontravam-se a do PDT, do PSB e do PPS (esquerda ou centro- esquerda), do PMDB, do PSDB (centro), do PR, do PSC, do PTC e do DEM (centro-direita ou direita). Todas registravam mais perdas do que ganhos, com exceção das bancadas do PR e do PSC, que tinham ganhado muito mais do que haviam perdido, 
do PTC, que tinha ganhado tanto quanto havia perdido, e do DEM, que só tinha perdido. No caso do PPS, do PSDB e do DEM, a quase totalidade das perdas havia sido para partidos governistas, notadamente para o PR.

\section{AÇÕes dos Deputados Federais}

\section{I PL N. I.210/2007 - REFORMA POLÍTICA}

Ao longo da 53 a Legislatura (2007-2011), diferentes propostas de mudança do sistema político adotado no Brasil foram apresentadas pelos deputados federais. Entre essas inúmeras proposições, este trabalho somente analisou preliminarmente aquelas que foram objeto de parecer. Deu-se especial destaque ao PL n. 1.210/2007, seja por reproduzir o inteiro teor do PL n. 2.679/2003, da Comissão Especial da Reforma Política, seja pelo alto interesse que despertou nos deputados dos diferentes partidos, ideologias e regiões do país - interesse demonstrado na intensa participação desses parlamentares na forma de emendas, pronunciamentos e questões de ordem -, seja por sua ampla repercussão na sociedade.

O PL n. 1.210/2007 propunha, entre outras alterações ao sistema eleitoral-partidário vigente, a proibição das coligações partidárias nas eleições proporcionais, a instituição de uma federação de partidos com duração mínima de três anos, a substituição da lista aberta pela lista fechada nas eleições proporcionais, o financiamento de campanha exclusivamente público e o estabelecimento de uma cláusula de desempenho por força da qual somente teriam direito a funcionamento parlamentar os partidos que, a cada eleição para a Câmara dos Deputados, houvessem obtido ao menos $2 \%$ dos votos apurados nacionalmente.

Encerrados a fase de discussão e o prazo para emendamento, em 27 de junho de 2007 o deputado Ronaldo Caiado, do DEM, relator da matéria, apresentou parecer pela rejeição de algumas emendas e aprovação de outras, na forma de substitutivo por ele então oferecido. Na realidade, de todas as emendas relacionadas aos principais itens da reforma proposta por meio do PL n. 1.210/2007, o deputado Ronaldo Caiado somente acolheu as que propunham a supressão da cláusula de desempenho eleitoral ou de barreira ao funcionamento parlamentar.

No mesmo dia, os deputados Luciano Castro, então líder da bancada do PR, e Miro Teixeira, então líder da bancada do PDT, requereram que o substitutivo do deputado Ronaldo Caiado fosse votado em grupo de artigos, figurando em primeiro lugar os artigos relacionados à lista fechada. Fruto de acordo, o requerimento foi aprovado em votação simbólica.

Submeteu-se, então, a votação o primeiro grupo de artigos do substitutivo do relator, os artigos relacionados à lista fechada. A lista fechada foi rejeitada por 252 a 181. Três deputados se abstiveram de votar. 
Em 4 de agosto de 2007, em uma derradeira tentativa de aprovar os demais itens - já flexibilizados - da reforma política, rejeitou-se, por votação simbólica, o segundo grupo de artigos do substitutivo do deputado Ronaldo Caiado, do DEM, para, em seguida, submeter-se a votação uma emenda aglutinativa substitutiva global ${ }^{7}$ apresentada pelo deputado Flávio Dino, do PCdoB, e elaborada com a ajuda do próprio deputado Ronaldo Caiado, entre outros interessados. Por meio dessa emenda aglutinativa substitutiva global, propunham-se o financiamento exclusivamente público somente para as eleições majoritárias e a proibição de integrar nova bancada partidária ao parlamentar que, no curso do mandato, se desfiliasse ou fosse desfiliado do partido de eleição.

A emenda aglutinativa substitutiva global, porém, não pôde ser admitida em razão de conter matéria nova ou não encontrada nem no projeto original nem nas muitas emendas a ele apresentadas, irregularidade suscitada, em questão de ordem, pelo deputado Arnaldo Faria de Sá, do PTB. Foi o melancólico fim da reforma política proposta por intermédio do PL n. 1.210/2007, um dos raros casos de proposições que, submetidas ao Plenário da Câmara, não resultaram aprovadas. Indagado quanto à intencionalidade do efeito, o deputado Flávio Dino respondeu:

Eu tinha e tenho convicção que a emenda aglutinava era correta, que ela... dentro evidentemente de uma certa interpretação regimental, porque o conceito regimental de emenda aglutinativa é repleto de conceitos jurídicos indeterminados, né? [...] Na verdade ali foi um gesto político - quando eu digo político não significa um juízo depreciativo -, foi um gesto político do presidente Arlindo [Chinaglia]. Naquele momento, acho que ele já estava convencido de que não ia adiante, que tava prolongando a agonia, que ia ficar o ônus político pra ele, já que a tentativa de retomada foi patrocinada por ele. Foi ele que chamou pra si, ele que assumiu, ele que coordenou nos momentos iniciais. E naquele instante, acho que ele já via que não havia condições de aprovar um texto que fosse adiante viabilizado, né? Um texto que fosse viável depois ser discutido no Senado. É interessante notar que naquele instante havia também muita resistência dos chamados "formadores de opinião”, de analistas, mundo acadêmico, editorialistas, jornalistas, que é um dos aspectos mais peculiares e curiosos da reforma política. Quando ela não é feita, há um discurso desses setores dizendo: “O Congresso não faz porque não quer”. E quando qualquer coisa é pautada, essa qualquer coisa é objeto de críticas, na maioria das vezes, na minha avaliação, disparatadas, como se houvesse aqui um amontoado de mal-intencionados ou ignorantes, que não tivessem a menor noção do que seria uma verdadeira reforma política. A questão que entre ter metafisicamente, idealmente, uma noção do que seria a reforma política e viabilizá-la aqui concretamente, no mundo 
material, com todas as suas contradições, há uma distância enorme.

Naquele momento, havia um... Nós estávamos em minoria também na sociedade. Não na sociedade, o povo. Porque o povo não acompanha o tema de reforma política, um tema para iniciados. Infelizmente é um tema muito distante da maioria do povo. Mas entre esses segmentos acadêmicos, jornalistas. Eu lembro de editoriais dizendo que seria eleição indireta, que iria privar o cidadão do direito ao voto, que o financiamento público seria desperdiçar dinheiro que poderia ir para o combate à fome, para construir casa para o povo. E esse aspecto também, na minha avaliação, influiu nessa decisão do presidente Arlindo (Entrevista realizada em 11/5/2010).

Ao longo de todo o processo de apreciação da reforma política proposta por meio do PL n. 1.210/2007, as bancadas do PSB, do PPS, do PMDB, do PSDB e do DEM foram as que se mostraram menos coesas. ${ }^{8}$ No outro extremo, as bancadas que se revelaram menos incongruentes em torno da matéria foram as do PCdoB, do PDT, do PSOL, do PR e do PSC. As bancadas do PT, do PV, do PP e do PTB, em uma zona intermediária, comportaram-se de forma mais ou menos inconsistente.

As poucas bancadas partidárias que até o fim se mostraram favoráveis à reforma política proposta por intermédio do PL n. 1.210/2007, à exceção do DEM, comportaram-se de modo relativamente coeso. Foram elas as bancadas do PCdoB, do PSOL e do PT - as duas primeiras mais congruentemente do que a última -, todas bancadas de esquerda ou centro-esquerda. Esse fato talvez se explique pela razão aduzida pelo então líder da bancada do PT, deputado Luiz Sérgio, para justificar o fechamento de questão daquele partido a favor da reforma proposta: os partidos de esquerda costumam preferir as ações coletivas às individuais. Tal razão também explicaria por que pequenas bancadas partidárias como as do PCdoB e do PSOL se dispuseram a votar a favor de uma reforma política que, em seu conjunto, penalizaria as agremiações menores. Uma coisa parece muito clara: os dirigentes do PCdoB, do PSOL e do PT sabiam e sabem que não poderão sobreviver por muito tempo como partidos que privilegiam as ações coletivas em um sistema político que induz a um comportamento individualista, particularista, personalista - enfim, antipartidário e antipolítico.

Como, então, explicar/compreender, de um lado, a ação das demais bancadas de esquerda ou centro-esquerda, que se revelaram contrárias à reforma política, e, de outro, o comportamento da bancada do DEM, que, sendo de direita ou centro-direita, se mostrou favorável à reforma, ainda que de forma pouco coesa?

Tanto a bancada do PDT, mais consistentemente, como as bancadas do PV, do PSB e do PPS, de maneira menos sólida, todas de esquerda ou de centro-esquerda, votaram contrariamente à reforma política proposta por meio do PL n. 1.210/2007. De acordo com o assessor do PDT entrevistado, em que pesasse à direção do partido ser favorável à reforma proposta, a bancada na Câmara era contra, e isso por razões bem pragmáticas: 
É o espírito de corpo do Parlamento. Ninguém quer saber de lista, porque acha que a lista acaba beneficiando as cúpulas partidárias e os deputados ficam de fora, perdem o poder por isso [...] Eu vou separar as coisas, a cúpula do partido e a sua bancada [...] A bancada é contra, porque aquilo ali implicava sua própria sobrevivência (Entrevista realizada em 20/3/2010).

Igual temor foi manifestado pelo deputado Miro Teixeira: "Ora, como é que seriam organizadas essas listas? Os mais submissos à frente, botando talvez um notável na cabeça da lista e depois o pessoal que tem o contracheque do partido" (Entrevista realizada em 6/5/2010).

$\mathrm{O}$ mesmo se pode dizer da pequena bancada do PV, integrada por deputados de tradições políticas as mais diversas, como é o caso do deputado Sarney Filho, que já esteve filiado à Aliança Renovadora Nacional (Arena), ao Partido Democrático Social (PDS/PP) e ao Partido da Frente Liberal (PFL/DEM) antes de aderir aos verdes: cada qual estava mais preocupado em garantir a própria sobrevivência política. $\mathrm{Na}$ avaliação do assessor entrevistado,

o tema reforma política, com o perdão da palavra, é alguma coisa que cada um conhece muito bem e sabe onde que aperta, onde que afrouxa, aonde que seu umbigo pode ir, aonde não pode. Eu diria que a coisa se capilariza a ponto de as questões regionais, paroquiais, até as questões que envolvem seu bairro, seu distrito, passam a ser muito mais relevantes do que qualquer questão nacional, partidária. Então essa característica do tema faz com que, num primeiro momento, você não tenha bancada, não tenha nem partido; você tenha a realidade e lógica do parlamentar. Então, quando se falam os vários temas que à época eram elencadas - lista aberta, lista fechada, financiamento público, financiamento privado -, todos esses temas são muito sensíveis a cada um deles. E nessa hora, cada um vê a sua realidade (Entrevista realizada em 14/4/2010).

Além disso, não se pode esquecer que o $\mathrm{PV}$ foi um dos partidos que, na $53^{\mathrm{a}}$ Legislatura (2009-2011), mais ganharam deputados de outras legendas. Ou seja, o PV só vinha lucrando com o atual sistema eleitoral-partidário.

Já as bancadas do PSB e do PPS estavam mais seriamente divididas em torno da reforma política proposta por intermédio do PL n. 1.210/2007. Uns poucos integrantes da bancada do PSB, como a deputada Luiza Erundina, ao longo de todo o processo se posicionaram a favor da reforma proposta. A maioria, porém, nas palavras do assessor entrevistado, estava 
voltada a sua realidade lá, dentro do partido lá em seus estados [...] É uma coisa bem do parlamentar mesmo. Cada um sabe onde está apertando seu calo... Cláusula de barreira, coligações... [...] A discussão dela [Luiza Erundina], como a dos outros que defenderam veementemente essa questão, tava além disso. Não tava muito focada nessa questão da sua sobrevivência [...] Vai muito da capacidade e da condição de cada parlamentar - no caso, exemplifico com a própria deputada Luiza Erundina - de sair um pouco desse processo e ver como isso pode trazer mais benefício [...] Eu acho que essa questão da sobrevivência foi o foco mesmo (Entrevista realizada em 12/4/2010).

Não se pode olvidar que o PSB vinha sendo sucessivamente controlado por personalidades como Miguel Arraes e Anthony Garotinho, e que a bancada daquele partido era a que, naquela legislatura, possuía o maior número relativo de deputados eleitos por votos próprios. Os socialistas não pareciam, pois, estar muito incomodados com o personalismo a que induz o sistema eleitoral-partidário vigente.

A bancada do PPS, que, juntamente com as bancadas do PSDB e do DEM, tinha perdido deputados para bancadas governistas, no início, embora pouco coesamente, vinha posicionando-se favoravelmente à reforma política. Ao final, mostrou-se tão severamente fragmentada que seu então líder, o deputado Fernando Coruja, viu-se forçado a liberá-la. Também aqui a maior parte da bancada revelou-se finalmente muito mais preocupada com a própria sobrevivência política: 60\% votaram contra a reforma. No julgamento do assessor do PPS entrevistado,

a questão realmente foi a lista fechada. E a lista por causa do presidente do partido, que era considerado... Aquele problema: "Espera aí, se o Roberto Freire for o que vai indicar o deputado, nós...” Por exemplo, o Humberto Souto, que tem uma história de líder do [Fernando] Collor [de Mello] e tal, seria um dos primeiros a não serem beneficiados nessa lista fechada [...] A maioria dos deputados, eles são contra. Eles querem ter o direito deles colocarem... não ser aquela coisa centralizadora. "O partido pensa assim, então eu vou ser banido se eu falar diferente disso" [...] Como eu te disse, a gente só tem o Augusto [Carvalho] de DNA comunista. O resto vem depois, do PPS. As origens deles não são de esquerda [...] O Humberto Souto especialmente, que era da Arena, PDS, foi líder do Collor, lutou contra o impeachment e agora tá com a gente no PPS [...] A questão estaria na lista. Porque eles imaginaram: "Pronto, só vão ter dinossauros, né?" O esqueleto do Partido Comunista ainda é o mesmo, né? O Roberto Freire e companhia limitada, que vêm desde lá atrás. Então todos eles, inclusive o Raul Jungmann, que é um cara 
superpartido, todos eles tiveram receio (Entrevista realizada em 5/4/2010).

Essa também foi a avaliação do próprio deputado Fernando Coruja:

Nós tínhamos um acordo de liberdade nessa matéria. O partido não fechou questão [...] A bancada não tinha uma opinião coesa nessa questão. $\mathrm{Eu}$, individualmente como parlamentar, tinha essa opinião. Mas lá, quando $c \hat{e}$ vai orientar, cê não orienta: "Eu acredito nisto. Tô orientando você a votar nisto" [...] Então, nesse caso da reforma política, a bancada já tinha discutido e não tinha chegado a uma uniformidade de posição.

[...]

Um dos principais problemas desse sistema eleitoral, como não há partidos e a pessoa não é eleita por uma lista partidária fechada, fica muito difícil cê ter aglutinação, mesmo que o partido decida uma coisa. A não ser que ele feche a questão [...] as pessoas tendem a votar como elas querem. Não há uma responsabilidade com o partido. Não há uma responsabilidade com a mudança. O sistema eleitoral leva a uma irresponsabilidade do Parlamento. A única responsabilidade que o parlamentar tem [...] é com a própria reeleição. Ele não tem responsabilidade com o governo. Esse troço não é parlamentarista. Logo ele não tem responsabilidade. Ele não tem responsabilidade com o partido, porque ele não é eleito pelo partido. Ele tende a votar de acordo com os seus interesses, o interesse dos seus eleitores especificamente. Se ele é religioso, ele vai votar de acordo com a sua religião. Se ele representa uma corporação, ele vota com sua corporação. Ele não vota com o partido [...] Como não tem partidos, fica difícil ter coesão na votação. Como não tem coesão na votação, fica difícil fazer reforma. No Brasil, se não fizer reforma não tem partido. Cada parlamentar é uma instituição (Entrevista realizada em 28/4/2010).

Como no caso do PDT, percebe-se no PPS uma clara divisão entre, de um lado, dirigentes partidários, preocupados com a continuidade do partido como uma agremiação política que privilegia as ações coletivas, favoráveis, por conseguinte, à mudança das regras políticas atuais, que induzem a um comportamento individualista, particularista e antipartidário, e, de outro, integrantes de bancadas parlamentares sem muito compromisso ideológico-programático com o partido, a maioria dos quais com um longo histórico de migração partidária.

E quanto à bancada do DEM, o que a teria levado, ainda que incongruentemente, a se posicionar a favor da reforma política proposta por meio do PL n. 1.210/2007? Dissidente do PDS, partido que sucedeu a Arena, portanto arraigada na tradição liberal, 
a maioria democrata que votou a favor da reforma proposta, inclusive sua nova liderança mais ao Sul, não deve havê-lo feito motivada por uma preferência pelas ações coletivas. Da mesma forma, a bancada do DEM não se deve ter posicionado favoravelmente à reforma política apenas porque ela beneficiaria os maiores partidos. Outras grandes bancadas, como a do PR, mais coesamente, e as do PP, do PSDB e do PMDB, de modo menos congruente, votaram contrariamente à reforma. Talvez a resposta possa ser encontrada no fato de ser o DEM o partido de grande porte que mais vinha perdendo com as regras políticas atuais. Como se viu, foi a legenda de grande porte que mais deputados perdeu para outras siglas, em sua maioria governistas, ${ }^{9}$ sem ganhar um sequer em troca. Além disso, a nova liderança mais ao Sul, conforme declaração do deputado Ronaldo Caiado adiante transcrita, acreditava que a reforma proposta emanciparia o DEM da tutela do PSDB, possibilitando-lhe lançar, em paridade de condições com os outros partidos maiores, candidato próprio a presidente da República.

No lado oposto, encontravam-se os partidos que só vinham lucrando com o atual sistema eleitoral-partidário e, por conseguinte, tinham interesse em conservá-lo. Como se observou, o PR, o PSC, o PP, o PTB e o PV - cujas bancadas se posicionaram, as duas primeiras mais, as três últimas um pouco menos consistentemente, contra a reforma política proposta por meio do PL n. 1.210/2007 - foram os partidos que, na $53^{\mathrm{a}}$ Legislatura, mais ganharam deputados de outras legendas, sem perder nenhum ou quase nenhum. Não deve ter sido por outra razão que o deputado Luciano Castro, então líder do PR - poucos dias depois de o PL n. 2.679/2003, de que o PL n. 1.210/2007 é cópia fiel, haver sido incluído na ordem do dia do Plenário da Câmara -, apresentou tanto o PLP n. 35/2007, que estabelece, em sua versão original, a inelegibilidade como a única penalidade a ser aplicada aos parlamentares que troquem de partido, quanto o PRC n. 45/2007, que determina que a proporcionalidade para fins de composição da Mesa e das comissões da Câmara deva ser aferida no início de cada sessão legislativa. No julgamento do assessor do PR entrevistado,

isso aí foi uma demanda que houve dentro do partido, dos deputados, porque, analisando você vê que, nesse período pós-Mensalão e tudo, nós elegemos só 25. Aí depois acho que tomaram posse 37 ou 38, algo assim. E foi, se não tô enganado, até 53. Isso aí teve uma demanda dentro da bancada de você organizar a vida dos deputados aqui dentro [...] O PLP [n. 35/2007] era criando uma janela pra movimentação de parlamentares dentro do partido [...] e a Resolução [PRC n. 45/2007], ele tentava acomodar os deputados dentro das comissões, mas ele fazia ressalva que não tinha alteração nas presidências das comissões. Isso foi tentado pra conseguir o apoio das bancadas que tinham conseguido o maior número de deputados das eleições [...] Eu acho que você não pode dizer que o 
partido é um “partido legislativo”. É um pouco disso, mas também ele é um partido de origem nas urnas, mas também dos interesses daqueles deputados que se elegem por um outro partido, até mesmo por um problema local, e depois querem as benesses do governo. Então eles têm que migrar pra um partido pra que possam ter essa opção. E os partidos que existiam na época, creio eu que a melhor escolha teria sido o PR. Porque o PTB, a gente sabe que teve um problema. O presidente continuava tendo problema com o atual governo. O PP poderia ser uma escolha também. Mas os principais três partidos eram esses e o movimento foi pra dentro do PR, né? Então eu acho que existia esse problema de eleição... Um exemplo claro foi na eleição de 2006, que a gente tinha uma bancada de Minas, seis ou sete. Só que a gente não conseguia eleger esses seis ou sete. Então houve a saída. Nós ficamos, acho, com três ou quatro. Conseguimos reeleger três e depois esses que saíram voltaram de novo pro partido. Exatamente pelo quociente partidário na eleição local. Então tem essa acomodação [...] Então tem esse jogo político também visando à eleição. É muito o processo legislativo, mas também é muito a eleição. Porque o deputado sabe que se tiver seis, sete grandes deputados disputando uma eleição ele não... fica mais difícil pra ele dentro dum partido que não tenha tanto deputado que contém um número de voto (Entrevista realizada em 9/4/2010).

Afora isso, à exceção do PV, esses partidos são todos de direita ou centro-direita, o que também pode explicar o fato de se terem posicionado contra uma reforma política que privilegiava as ações coletivas. O PSC incorporou as ideias e os princípios do extinto Partido Democrático Republicano (PDR), e o atual PTB pode ter sido fruto da tentativa do governo militar de enfraquecer o grupo político de Brizola. O próprio deputado Arnaldo Faria de Sá, em 1988, então filiado ao Partido da Juventude (PJ), posteriormente denominado de Partido da Reconstrução Nacional (PRN), atualmente PTC, concorreu ao cargo de vice-prefeito de São Paulo na chapa de Paulo Maluf. Foi o mesmo Arnaldo Faria de Sá quem articulou a candidatura a presidente da República, pelo então PRN hoje PTC, de Fernando Collor de Mello. Assim, apesar da denominação, tanto o PSC quanto o PTB têm suas raízes fincadas numa tradição individualista, particularista, personalista e antipartidária.

E o que dizer das bancadas partidárias de centro? O que teria levado as bancadas do PSDB e do PMDB, ainda que pouco coesamente, a se posicionarem contra a reforma política proposta por intermédio do PL n. 1.210/2007? O PSDB, que, como o PPS e o DEM, vinha perdendo deputados sobretudo para partidos governistas, ${ }^{10}$ inicialmente havia fechado questão a favor da reforma política. Inaugurada a discussão no Plenário, no entanto, a pretexto de compromisso com a chamada "distritalização 
do voto”, o PSDB mudou de posição, chegando inclusive a fechar questão em sentido contrário. Sem embargo de serem críticos do sistema eleitoral-partidário vigente, os tucanos paulistas - o maior e mais influente grupo dentro do partido e da bancada - convenceram-se de que as regras atuais seriam mais favoráveis à formação de uma base de apoio à candidatura de José Serra a presidente da República. Na avaliação do deputado João Almeida, da Bahia,

lá atrás, quando o [José] Serra era candidato, era presidente do partido, o partido fechou questão exatamente no sentido contrário, em favor da lista partidária. E essa posição eu fui autorizado - não era líder, mas fui autorizado - pela Executiva Nacional e pela bancada a negociar essa posição, né? E vínhamos mantendo essa posição. Quando o projeto voltou a ser apresentado, no começo das discussões, o partido estava inclinado à lista, mas subitamente houve uma mudança de posição muito brusca e acabou resultando no que deu: o partido fechou questão no sentido contrário. E isso foi o motivo da derrota da proposta. A posição do PSDB é que foi definidora do resultado, né? Eu não procurei identificar bem isso, mas veio muito da bancada de São Paulo, pelo peso que tem a bancada de São Paulo, que mudou de posição. E eu acho que até por, de certo modo, por influência de novo agora do Serra no sentido contrário. Eu não sei... circunstância do momento. Mas como temos o hábito ruim de pensar nessas questões que são, digamos assim, permanentes da política vinculadas a circunstância eleitoral que tá muito próxima. Esta é a dificuldade que temos de fazer uma reforma política, mesmo a reforma eleitoral: a projeção do resultado daquilo na eleição que vai acontecer proximamente, né? (Entrevista realizada em 29/4/2010. Nessa ocasião, o deputado João Almeida era o líder da bancada tucana).

O julgamento do deputado Bonifácio de Andrada, de Minas Gerais, é no mesmo sentido:

Mas depois as lideranças paulistas, que dominam o partido, ficaram muito contra a lista, porque acham que o atual sistema é favorável para eles [...] Digamos que era o grupo paulista que estava querendo nos impor uma fórmula que convinha mais - não sei por que - às exigências do desenvolvimento político deles, dentro do partido (Entrevista realizada em 5/5/2010).

Na mesma direção também a avaliação do deputado Flávio Dino, do PCdoB, que teve uma atuação destacada em todo o processo, inclusive nos bastidores da Câmara: 
Logo na retomada do PL 1.210, houve um fato inesperado e, na nossa opinião, inusitado, que foi a mudança de posição do PSDB. O PSDB participou do entendimento anterior e por motivos, a meu ver, fincados mais na conjuntura política, no interesse de formar um campo político... O PSDB, na verdade, constituiu naquele momento a coluna vertebral do processo de resistência do PL 1.210, aglutinando em torno de si o PP, o PTB e o PR (Entrevista realizada em 11/5/2010).

No julgamento do deputado Ronaldo Caiado, do DEM, a estratégia dos tucanos paulistas de formar uma base de apoio à candidatura do tucano José Serra a presidente da República incluía a manutenção dos democratas sob a tutela do PSDB:

O PSDB se alinhou conosco na Comissão Especial. Na hora da votação do texto, ele votou contrário. Por quê? Porque o financiamento público, ele dá aos maiores partidos uma igualdade na distribuição do dinheiro e com isso você viabiliza a candidatura de todos esses partidos à presidência da República. Dentro do atual sistema, você só viabiliza a campanha eleitoral quem tem a máquina do governo hoje, que é o presidente, ou senão quem tem o comando dos grandes estados do Brasil, com grande poder de gasto. Então essas são as... os mecanismos aonde emergem os candidatos no Brasil [...] Quando o PSDB veio com a tese do voto distrital, ele veio única e exclusivamente para derrubar aquilo que criava uma condição que os partidos, principalmente o Democratas, o PSDB, o PT e o PMDB, eles teriam tempo de televisão próximos, quase idênticos, e nós teríamos uma distribuição em dinheiro também com pouca diferença. Então todos os quatro partidos, eles teriam total independência para lançar candidato (Entrevista realizada em 5/5/2010).

Finalmente, o PMDB. Do início ao fim do processo de apreciação do PL n. 1.210/ 2007, a bancada peemedebista foi a que se comportou de forma menos coesa em torno da reforma política proposta. Tão severa foi a fratura dos deputados do PMDB que o líder Henrique Eduardo Alves, depois de haver, ao longo de todo o processo, orientado a bancada a votar a favor da reforma, foi compelido, ao final, a liberá-la. $57 \%$ deles votaram contra a lista fechada. O comportamento da bancada peemedebista, contudo, não surpreende. O PMDB era o partido que mais vinha lucrando com as regras políticas atuais. Era a agremiação política brasileira que tinha o maior número de filiados, vereadores, prefeitos e governadores, além de possuir a maior quantidade de deputados federais e senadores. A par de seis ministérios do governo Lula, comandava ainda a Câmara dos Deputados e o Senado Federal. Não tinha interesse em alterar o status quo. ${ }^{11}$ 
2.2 PEC N. 5II / 2006 - LimitaÇÃO DOS PODERES LEGISLATIVO DO PRESIDENTE DA RepúbliCA Assim como aconteceu em relação ao sistema eleitoral-partidário, diversas propostas de mudança da distribuição de poderes legislativos foram apresentadas por deputados federais na 53 ${ }^{\mathrm{a}}$ Legislatura (2007-2011). Entre todas as proposições previamente analisadas, este trabalho dá especial enfoque à PEC n. 511/2006 e suas apensadas, basicamente pelas mesmas razões que destacou o PL n. 1.210/2007 ao examinar as ações dos deputados federais relacionadas ao sistema eleitoral-partidário: além de ter sido a única de tais proposições a ser apreciada pelo Plenário, foi a que mais despertou o interesse dos deputados, interesse demonstrado na intensa participação desses parlamentares inclusive na forma de emendas e pronunciamentos.

Na forma originalmente aprovada pelo Senado Federal, a PEC n. 511/2006 propunha, em suas grandes linhas, que as medidas provisórias editadas pelo presidente da República somente ganhassem força de lei depois de admitidas pela Comissão de Constituição e Justiça e de Cidadania (CCJC) da Casa do Congresso Nacional em que iniciassem sua tramitação; que, além de não poderem dispor sobre matéria tributária, as medidas provisórias tivessem objeto único, não podendo conter matéria estranha a esse objeto; e que somente entrassem em regime de urgência, sobrestando as demais deliberações legislativas, após transcorridos dois terços do prazo assinado a cada Casa Congressual.

A PEC n. 511/2006 foi apresentada ao Plenário da Câmara dos Deputados em 9 de fevereiro de 2006. Encerrado o prazo de emendamento na Comissão Especial, em $1^{\circ}$ de abril de 2008 o deputado Leonardo Picciani, do PMDB, relator da matéria, apresentou parecer à Comissão pela aprovação da PEC n. 511/2006, de suas apensadas e de todas as emendas, na forma de substitutivo por ele então oferecido. O deputado Leonardo Picciani não acatou o dispositivo da PEC n. 511/2006 em virtude do qual as medidas provisórias editadas pelo presidente da República somente ganhariam força de lei depois de admitidas pela CCJC da Casa do Congresso Nacional em que iniciassem sua tramitação nem a proposta de seu colega de bancada, o deputado Michel Temer, de acordo com a qual o chefe do Executivo poderia responder por crime de responsabilidade caso medida provisória por ele editada fosse rejeitada por Casa Congressual em razão da inexistência de urgência. Tampouco acolheu o deputado Leonardo Picciani qualquer das propostas de ampliação da limitação material do poder do presidente da República de editar medidas provisórias nem de estabelecimento de uma quantidade máxima de medidas provisórias que poderiam ser editadas a cada ano. Afora isso, em lugar do dispositivo da PEC n. 511/2006 em virtude da qual o chefe do Executivo não poderia editar medida provisória com mais de um objeto, o relator acolheu a proposta do deputado Flávio Dino, do PCdoB, que simplesmente vedava a falta de "homogeneidade temática" entre seus vários objetos.

As únicas propostas de limitação do poder do presidente da República de editar medidas provisórias efetivamente acatadas pelo deputado Leonardo Picciani foram a 
que suprimia o trancamento da pauta e a que proibia sua revogação. Entretanto, até mesmo o acolhimento da proposta de supressão do travamento da pauta restou ambíguo no substitutivo do relator:

Considerada admissível, ou não tendo sido apreciada a admissibilidade dentro do prazo, a medida provisória entrará em regime de urgência, passando a ocupar o primeiro lugar na Ordem do Dia do Plenário nas sessões ordinárias e extraordinárias (PEC n. 511/2006).

É difícil imaginar outro efeito da pretendida precedência das medidas provisórias senão o do trancamento da pauta. Ademais, o substitutivo do deputado Leonardo Picciani suprimiu a vedação constitucional da abertura de crédito suplementar por meio de medida provisória e acrescentou: "O projeto de lei de crédito suplementar e especial que, após decorrido o prazo de setenta e cinco dias de seu envio pelo Poder Executivo, não tenha sido incluído na Ordem do Dia do Congresso Nacional, poderá ser objeto de medida provisória”.

No dia 16 de abril de 2008, o deputado Leonardo Picciani, do PMDB, apresentou uma complementação de voto, incorporando ao substitutivo anteriormente ofertado parte das propostas dos deputados Flávio Dino, do PCdoB, e José Eduardo Cardozo, do PT. Assim, o substitutivo do relator passou a dispor, de maneira persistentemente ambígua, que

considerada admissível, ou não tendo sido apreciada a admissibilidade dentro do prazo, será indicado o relator para, em cinco dias, manifestar-se quanto ao mérito, bem como quanto à admissibilidade no caso de não apreciação, após o que a medida provisória entrará em regime de urgência, passando a ocupar, salvo deliberação contrária da maioria absoluta da Casa, o primeiro lugar na Ordem do Dia do Plenário nas sessões ordinárias e extraordinárias, não sobrestando a pauta de deliberação (PEC n. 511/2006).

O substitutivo do deputado Leonardo Picciani passou a conter ainda dispositivo permitindo ao presidente da República, dentro de determinado prazo, retirar medida provisória já em vigor e submetida à apreciação congressual.

Ao fim e ao cabo, o texto da PEC n. 511/2006 finalmente aprovado em primeiro turno pela Câmara dos Deputados em 17 de fevereiro de 2009 não representa qualquer avanço efetivo no sentido de limitar o poder legislativo do presidente da República em geral e sua prerrogativa de editar medidas provisórias em particular. Ao contrário, reduz o tempo que as Casas do Congresso Nacional dispõem para apreciar as medidas provisórias antes que elas passem a trancar a pauta e dá à maioria, em regra governista, a possibilidade de destrancá-la sempre que lhe convier. 
Desde sua aprovação em primeiro turno, a PEC n. 511/2006 ainda não foi submetida à apreciação em segundo turno. Talvez por ter perdido a importância em face da decisão do então presidente da Câmara, deputado Michel Temer, do PMDB, proferida um mês depois, em 17 de março de 2009, nos autos da Questão de Ordem n. $411 / 2009$, por força da qual as medidas provisórias não apreciadas no prazo constitucional apenas sobrestam as deliberações sobre matérias que possam ser objeto de medidas provisórias, não alcançando, portanto, PECs, PLPs, projetos de decreto legislativo (PDCs), PRCs e até mesmo PLs dispondo sobre matérias que não possam ser objeto de medidas provisórias.

Curiosamente, a contestação da decisão do presidente Michel Temer veio justamente dos deputados da oposição. Os deputados Fernando Coruja, José Aníbal e Ronaldo Caiado, respectivamente, líderes das bancadas do PPS, do PSDB e do DEM, impetraram um mandado de segurança junto ao STF, requerendo, cautelarmente, fosse o presidente da Câmara impedido de pautar PECs, PLPs, PLs, PDCs e PRCs até o julgamento definitivo do writ. ${ }^{12}$ No início do processo de apreciação da PEC n. $511 / 2006$ e suas apensadas, os deputados Roberto Magalhães e José Carlos Aleluia, do DEM, apresentaram emendas propondo a supressão do sobrestamento por medida provisória com prazo esgotado. Contudo, a partir de certa altura do processo, notadamente a partir da inserção no substitutivo do deputado Leonardo Picciani, do PMDB, por proposta do deputado José Eduardo Cardozo, do PT, de dispositivo que permitia à maioria afastar o sobrestamento, os democratas passaram a perceber que o fim do sobrestamento ou, sobretudo, a possibilidade de seu afastamento por deliberação da maioria enfraqueceria seu poder de obstrução. Já os tucanos, sempre na expectativa de voltar a governar, viam no sobrestamento um importante mecanismo de contenção da "irresponsabilidade fiscal" do Congresso Nacional. A liminar foi indeferida em 27 de março de 2009 (cf. Cautelar em Mandado de Segurança n. 27.931-1 Distrito Federal). Desde então, sem embargo de a pauta estar trancada por medidas provisórias com prazo esgotado, a Câmara dos Deputados vem apreciando, em sessões extraordinárias, PECs, PLPs, PLs dispondo sobre matérias que não possam ser objeto de medidas provisórias, PDCs e PRCs.

No decorrer de todo o processo de apreciação em primeiro turno da PEC n. 511/ 2006, que se arrastou por mais de três anos, as bancadas do PDT, do PPS, do PSDB, do PP, do PSC e do DEM foram as que se mostraram menos coesas. No outro extremo, as bancadas que se revelaram mais congruentes foram as do PT, do PMDB, do PR e do PRB, todas governistas e favoráveis ao substitutivo aprovado pela Comissão Especial. Em uma zona intermediária, comportaram-se um pouco menos consistentemente as bancadas do PCdoB, do PSB, do PV, do PSOL e do PTB.

As bancadas oposicionistas - do PPS, do PSDB e do DEM - ${ }^{13}$ comportaram-se de modo menos coeso, notadamente na votação mesma do substitutivo da Comissão Especial, ocasião em que também foi verificada a maior porcentagem média de 
incongruência das bancadas. As bancadas do PPS e do PSDB chegaram inclusive a mudar de posição, vindo a votar favoravelmente ao substitutivo.

O PSDB, como se sabe, já governou o país e sempre trabalha com a possibilidade de voltar a ser governo. Costuma, portanto, fazer uma oposição um tanto mais responsável. Além disso, no julgamento do assessor do PSDB entrevistado,

a questão do sobrestamento da pauta por medida provisória é uma questão em debate, tanto nas bancadas governistas quanto nas bancadas de oposição. Nas bancadas governistas, é o poder do presidente de equilibrar a pauta. Nas bancadas de oposição, hoje isso tem como um antídoto para a permissividade do Parlamento. Hoje convém, em determinados momentos [...], a pauta estar trancada, para não se ver matérias indesejadas, em especial de aumento de despesa [...] O trancamento da pauta é uma estabilidade dada pra futuros governos (Entrevista realizada em 29/3/2010).

O PPS usualmente acompanhava o partido dos tucanos. Além disso, na avaliação do assessor do PPS entrevistado,

no limite, ficou um pouco difícil de explicar pra sociedade porque que o PPS também era contra [...] A gente esticou a corda até aonde pôde. Teve um momento que estava difícil a gente explicar que era contra a reforma da medida provisória [...] Normalmente quem continua é o DEM, que faz uma oposição petista, né? (Entrevista realizada em 5/4/2010).

De fato, os democratas, de longe os menos consistentes durante todo o processo de apreciação em primeiro turno da PEC n. 511/2006, fizeram uma oposição igualmente menos consequente: estiveram à testa de quase todas as medidas obstrucionistas aparelhadas contra a votação do substitutivo e dos vários destaques.

Já as bancadas governistas, em sua grande maioria, comportaram-se de maneira mais coesa a favor do substitutivo da Comissão Especial, em que pesasse ao fato de integrantes de um número considerável delas, inclusive da bancada do PT, haver apresentado PECs ou emendas propondo a redução do poder do presidente de editar medidas provisórias. Com efeito, todas as bancadas governistas - apenas três de forma menos congruente: PDT, PP e PSC - , seguindo a orientação do líder do governo, votaram favoravelmente ao substitutivo e contrariamente a todos os requerimentos obstrucionistas e os destaques da oposição. ${ }^{14}$

\subsection{Análise comparada}

As bancadas partidárias da Câmara dos Deputados, em geral, comportaram-se de modo visivelmente mais coeso no processo de apreciação da PEC n. 511/2006, das 
medidas provisórias, do que no do PL n. 1.210/2007, da reforma política. Enquanto o índice médio de incongruência nas votações referentes a esta última proposição alcançou $18 \%,{ }^{15}$ atingiu apenas $8 \%$ nas votações atinentes à primeira. Além disso, algumas bancadas evoluíram ao longo do processo de apreciação da reforma política proposta por meio do PL n. 1.210/2007: algumas de uma posição favorável para uma contrária à reforma - as bancadas do PPS, do PMDB e do PSDB; outras ganharam consistência - as bancadas do PT e do PSOL a favor da reforma e a bancada do PV contra; ainda outra perdeu solidez - a bancada do DEM favoravelmente à reforma.

Mas não apenas isso. Houve uma maior articulação entre as bancadas no processo de apreciação da PEC n. 511/2006 do que no do PL n. 1.210/2007. Aliás, na apreciação do PL n. 1.210/2007, não se percebeu qualquer articulação entre as bancadas partidárias: bancadas de esquerda ou centro-esquerda e de direita ou centrodireita, grandes e pequenas, governistas e oposicionistas, votaram umas favoravelmente e outras contrariamente à reforma política proposta.

Já na apreciação da PEC n. 511/2006, à exceção da fase de emendamento na Comissão Especial, desde o início do processo constatou-se uma clara articulação entre as bancadas partidárias: as bancadas governistas, de esquerda ou centro-esquerda, de centro e de direita ou centro-direita, grandes e pequenas, todas invariavelmente se posicionaram a favor do substitutivo da Comissão Especial, ao passo que se posicionaram contra o substitutivo todas as bancadas de oposição. A bancada do PSOL, independente em relação tanto ao governo como à oposição, alinhou-se com esta última contra o substitutivo.

Esse contraste verificado no comportamento das bancadas partidárias nos dois processos legislativos se explica sobretudo pelo fato aduzido pelo deputado Gerson Peres, do PP, no início da discussão do PL n. 1.210/2007: "Declarou o Presidente Lula que a reforma política é assunto dos Parlamentares e que o Governo não interferirá, porque essa é uma questão de consciência parlamentar” (PL n. 1.210/2007). A decisão do governo de não interferir no processo de apreciação da reforma política proposta por intermédio do PL n. 1.210/2007 foi posteriormente anunciada por seu líder na Câmara, ao liberar as bancadas que lhe dão sustentação naquela Casa: "Sr. Presidente, a liderança do Governo não tem posição sobre a matéria. Caberá aos partidos definir a situação política do País” (PL n. 1.210/2007). Na realidade, de acordo com o deputado Raul Henry, do PMDB, o governo estava sob forte pressão de vários partidos que compunham sua base de sustentação na Câmara:

Houve inicialmente uma tendência pró-reforma política. O deputado Ibsen Pinheiro [PMDB] teve um papel... Posteriormente o tapete dele foi puxado aqui com a reorientação da bancada, com o pretexto de que isso ia criar problemas pra base do governo, que os partidos pequenos aqui da 
base do governo - o PP, o PTB, o PR - não queriam essa reforma. E colocar esse tema em votação, colocar esse tema na agenda daqui, ia criar problemas pra base do governo (Entrevista realizada em 11/5/2010).

Essa pressão exercida notadamente pelo $\mathrm{PP}$, pelo $\mathrm{PR}$, pelo $\mathrm{PTB}$ e por parte do PMDB - o grupo do Rio - sobre o governo foi confirmada pelo deputado Ronaldo Caiado, do DEM:

Foi uma pressão para que o modelo não fosse alterado, comandada por uma rebelião na base do governo. Isso foi citado na reunião de líderes pelo PP, pelo PR, pelo PTB, com conivência do PMDB. Isso foi o fato que resistiu e que impactou negativamente a reforma. Eles ameaçavam sair da base do governo ou votar favoravelmente às CPIs. Essa é que é a realidade. Quem encabeçou, quem botou a cara para poder derrubar o projeto foram esses partidos, o PTB, o PR, o PP, aí acrescido com uma dissidência dentro do PMDB (Entrevista realizada em 5/5/2010).

Por sua vez, no que toca à PEC n. 511/2006, percebeu-se uma ostensiva atuação do governo tanto pela aprovação do substitutivo da Comissão Especial, que ampliava seus poderes de agenda, quanto pela rejeição dos destaques das bancadas de oposição, que pretendiam podar-lhe os excessos. Diferentemente do que aconteceu no decorrer do processo de apreciação do PL n. 1.210/2007, nas votações do substitutivo à PEC n. 511/2006 e de seus vários destaques, o governo nunca deixou de orientar as bancadas que lhe davam sustentação.

Fica, pois, evidente que as bancadas partidárias da Câmara dos Deputados se comportam internamente de maneira mais coesa e mais articulada entre si quando há um claro interesse do governo em jogo. Dependendo do grau desse interesse, o governo não costuma encontrar, no interior da Câmara dos Deputados, resistência importante a suas pretensões. Pelo menos foi esse o caso da PEC n. 511/2006. Todos os integrantes de bancadas governistas que haviam apresentado PECs conexas e inicialmente ofereceram emendas à PEC n. 511/2006 propuseram, de um modo ou de outro, a redução do poder do presidente da República de editar medidas provisórias. A despeito disso, uma vez iniciado o processo de apreciação pelo Plenário, todas essas bancadas - umas poucas de maneira incongruente, mas todas invariavelmente - passaram a votar de acordo com a orientação do líder do governo, a favor da manutenção ou mesmo da ampliação dessa prerrogativa do chefe do Executivo.

Ademais, o governo conseguia votos até mesmo dentro da bancada que mais se destacou na oposição ao substitutivo da Comissão Especial: a do DEM. Além de haver previamente atraído para suas fileiras - aliás, para bancadas que lhe davam sustentação, notadamente a do PR - 21\% dos deputados eleitos sob aquela legenda, 
o governo obtinha, a cada votação referente à PEC n. 511/2006, uma quantidade significativa de votos entre os democratas. Em uma das votações - a do destaque que permitiria ao presidente da República abrir créditos especiais e suplementares por meio de medidas provisórias -, o governo chegou a obter 35\% dos votos da bancada do DEM.

Nesta quadra, vale destacar as reclamações feitas por deputados da oposição no decorrer do processo de apreciação da PEC n. 511/2006. O deputado Duarte Nogueira, do PSDB, protestou contra o fato de o governo estar "atropelando como um trator a Minoria” (PEC n. 511/2006). Denunciou, por sua vez, o deputado Paulo Bornhausen, do DEM:

Temos um número de Deputados menor do que pressupõe a sociedade com relação às maiorias. A Oposição que está aqui hoje não é a que foi eleita pelo voto popular; ela era muito maior do que a que está aqui hoje. Porque houve uma migração de Parlamentares que foram eleitos por partidos de oposição (PEC n. 511/2006).

\section{CONSIDERAÇÕES FINAIS}

Este trabalho procurou combinar uma explicação das ações dos deputados federais da 53 2 Legislatura (2007-2011), a partir de elementos estruturais, sobretudo as constrições e as potencialidades objetivas inscritas nas estruturas partidárias, com uma compreensão das representações que esses parlamentares faziam da própria conduta.

Análises como a de Argelina Figueiredo e Fernando Limongi (1999), além de ignorar essa dimensão subjetiva elementar, constitutiva da ação em geral e do comportamento parlamentar em particular, somente levam em conta as votações nominais em que não há unanimidade nas orientações dos líderes. Ora, o exame dos processos de apreciação do PL n. 1.210/2007 e da PEC n. 511/2006, objeto deste trabalho, deixa claro que a mera análise de atos isolados desses e de outros processos não é capaz de capturar aspectos elementares, constitutivos, envolvidos inclusive nas votações.

No curso do processo explicativo-compreensivo das ações dos deputados federais daquela legislatura, ficou evidente que o sistema político adotado no Brasil, sobretudo a combinação de presidencialismo com proporcionalismo de lista aberta, tem exercido considerável influência sobre o comportamento parlamentar.

As regras políticas vigentes têm concorrido - juntamente com outros fatores, notadamente culturais - para a formação de uma multiplicidade de partidos fracos, com pouca capilaridade social, identidade ideológico-programática e coesão. Essas agremiações, em geral, são constituídas de políticos individualistas, particularistas, personalistas e com longo histórico de migração partidária. Na 53ª Legislatura (2007-2011), 
em que pesasse à decisão do Tribunal Superior Eleitoral (TSE) (Resolução n. 22.610/ 2007), em resposta à Consulta n. 1.398/2007, do PFL/DEM, referendada pelo STF (Mandado de Segurança n. 26.602), por força da qual perde o cargo eletivo o mandatário que, sem justa causa, desfiliar-se do partido, somente as bancadas do PCdoB, do PSOL, do PMN e do DEM não receberam deputados eleitos por outras legendas. Respectivamente, 52\%, 85\% e 44\% das bancadas do PR, do PRB e do PSC migraram de outras siglas. Partidos com essas características dificilmente conseguem fechar questão em torno de qualquer assunto. No processo de apreciação da reforma política proposta por meio do PL n. 1.210/2007, somente o PCdoB, o PT e o PSDB foram capazes de fazê-lo. Isso, no entanto, não garantiu que todos os integrantes das bancadas desses partidos na Câmara dos Deputados seguissem a orientação de seus líderes em todas as votações havidas. Tais partidos, igualmente, não têm pretensão de ser governo. Auferem maiores lucros posicionando-se na nebulosa região fronteiriça entre o governo e a oposição. Nas últimas eleições gerais, agremiações como o PMDB, o PP, o PR e o PTB não lançaram candidato ao cargo de presidente da República, havendo apoiado os diferentes grupos que se alternaram no governo.

A fragilidade, o pragmatismo e a incongruência dos partidos, bem como o individualismo, o particularismo e o apartidarismo dos integrantes de suas bancadas congressuais, são tamanhos que o governo, a cada votação importante, tem de negociar com sua base de sustentação, muitas vezes num plano individual. Como disse o deputado João Almeida, líder da bancada do PSDB em 2010,

o sistema eleitoral nosso é péssimo, ele não atende as necessidades de constituição de uma base para o governo que se instala, seja ele federal ou municipal ou estadual, especialmente federal, para garantir governabilidade com qualidade. O que que eu chamo de governabilidade com qualidade? É fundada na realização de um programa de governo, tá? Quer dizer, a forma como se constitui essa maioria hoje, dada essa pulverização partidária, que resulta do nosso sistema eleitoral, é de muito baixa qualidade e é muito suscetível de mudanças de acordo com os humores momentâneos do Congresso, de certos grupos de pressão do Congresso. E os entendimentos que fazem os governantes com os partidos não dão estabilidade ao processo. A cada votação, há que se fazer uma nova negociação, não é? Garantir a participação dos partidos no governo, com posições de destaque, ministérios etc., não garante nada. Nas votações, todas... a maioria das votações críticas, importantes, que significam mudança de rumo, reforma etc., tem que negociar, e negociar com cada deputado, com cada grupo de pressão que se organiza aqui dentro. Isso é uma tragédia para o processo legislativo, para a governabilidade por conseguinte e para o governo poder realizar metas de médio e longo prazos (Entrevista realizada em 29/4/2010). 
Na mesma direção, como se observou, a avaliação do deputado Fernando Coruja, líder da bancada do PPS na legislatura passada:

Um dos principais problemas desse sistema eleitoral, como não há partidos e a pessoa não é eleita por uma lista partidária fechada, fica muito difícil $c \hat{e}$ ter aglutinação, mesmo que o partido decida uma coisa [...] as pessoas tendem a votar como elas querem. Não há uma responsabilidade com o partido. Não há uma responsabilidade com a mudança. O sistema eleitoral leva a uma irresponsabilidade do Parlamento. A única responsabilidade que o parlamentar tem [...] é com a própria reeleição. Ele não tem responsabilidade com o governo. Esse troço não é parlamentarista. Logo ele não tem responsabilidade. Ele não tem responsabilidade com o partido, porque ele não é eleito pelo partido. Ele tende a votar de acordo com os seus interesses, o interesse dos seus eleitores especificamente. Se ele é religioso, ele vai votar de acordo com a sua religião. Se ele representa uma corporação, ele vota com sua corporação. Ele não vota com o partido. Ele não vota com o partido, ele vota com a corporação, ele vota com a religião [...] Como não tem partidos, fica difícil ter coesão na votação [...] Cada parlamentar é uma instituição (Entrevista realizada em 28/4/2010).

Essa fraqueza dos partidos políticos se reflete na fragilidade das lideranças partidárias nas Casas Legislativas em geral e na Câmara dos Deputados em particular. Ao contrário do que acreditam Argelina Figueiredo e Fernando Limongi (1999), em que pese aos instrumentos regimentais postos a sua disposição, os líderes partidários não influenciam, de modo decisivo, o comportamento das respectivas bancadas. Em primeiro lugar, essa estrutura de lideranças partidárias não está tão concentrada hoje quanto já esteve no regime militar e, mais ainda, no regime de 1946 a 1964 . Além disso, as indicações que faz o líder costumam ser meramente formais. Com a escolha do líder, é comum já ficar definido quem participará dessa ou daquela comissão e, em alguns casos, quem presidirá a comissão tal ou qual. Até mesmo na reunião de líderes, a força da opinião de cada um é medida pela percepção de todos de quão representativa essa opinião é dos sentimentos da bancada. O parecer de líder que não é percebido como representativo dos sentimentos da maioria da bancada ou do grupo que controla a bancada não é usualmente levado a sério. Afinal, o presidente não quer correr o risco de submeter ao Plenário uma proposta que não tenha o apoio das principais forças políticas existentes na Casa. O mesmo se dá no que concerne às orientações dos líderes no Plenário. Como declarou o deputado Fernando Coruja, líder da bancada do PPS, “o líder, ele não chega lá e orienta sem conversar. Ele leva a orientação da bancada [...] A orientação é uma orientação de uma decisão coletiva 
da bancada" (Entrevista realizada em 28/4/2010). O assessor do DEM, malgrado todo esforço para realçar a força da liderança da bancada dos democratas, deixou transparecer que o líder pode ser substituído caso ele contrarie a maioria da bancada:

Sempre nas decisões polêmicas - sempre não, mas na maior parte das vezes -, o líder ouve a bancada nas reuniões de bancada de terça-feira [...] Geralmente, nos temas polêmicos, ele sempre consulta. E é prudente ele consultar, até pra ele não ser desautorizado e derrubarem ele, pra metade mais um, a maioria absoluta da bancada não se juntar e indicar outro líder (Entrevista realizada em 14/4/2010).

O assessor do PMDB resumiu bem o papel do líder das bancadas partidárias, notadamente as governistas: O líder está "ali pra atender a todos e não contrariar ninguém” (Entrevista realizada em 29/4/2010). Não foi por outro motivo que, depois de vir orientando a favor da reforma política ao longo de todo processo, ao final, na votação do grupo de artigos do substitutivo do deputado Ronaldo Caiado referente à lista fechada, os líderes do PPS e do PMDB sentiram-se compelidos a liberar as respectivas bancadas.

Em um ponto, pelo menos, Figueiredo e Limongi (1999) têm razão: o presidente da República e a burocracia governamental têm ocupado todos os vazios de poder que os partidos e as lideranças partidárias não têm sido capazes de preencher na estrutura do Congresso Nacional em geral e da Câmara dos Deputados em particular. Ademais de instrumentos constitucionais como a iniciativa exclusiva de algumas leis, inclusive as orçamentárias, a prerrogativa de atribuir urgência a projetos de lei de sua autoria e a edição de medidas provisórias com força de lei, por meio dos quais controla a pauta das Casas congressuais, o chefe do Executivo dispõe também de eficientíssimos mecanismos de cooptação de parlamentares: detém o controle do orçamento da União e de milhares de cargos de livre nomeação na administração pública, direta e indireta.

Com essas poderosíssimas armas em mão, o governo tem desempenhado um papel determinante na configuração do tabuleiro político na Câmara dos Deputados, atraindo para as bancadas dos partidos que lhe dão sustentação parlamentares eleitos por legendas de oposição. Na 53ª Legislatura (2007-2011), o PPS, o PSDB e o DEM perderam, respectivamente, $41 \%, 12 \%$ e $21 \%$ de suas bancadas de eleição, dos quais $100 \%$, $88 \%$ e $93 \%$ migraram para partidos que integravam a base governista na Câmara, notadamente o PR. Vale realçar as palavras do assessor daquele partido: o PR "é um partido de apoio à base. Foi fundado pra isso. Teve o apoio do governo pra ter essa movimentação de deputados vindos pra cá" (Entrevista realizada em 9/4/2010).

Mas isso não é tudo. O governo tem influenciado até mesmo a escolha e a manutenção dos líderes das bancadas dos partidos que lhe dão sustentação naquela Casa. 
Isso ficou bastante evidente nas entrevistas. De acordo com o deputado Miro Teixeira, do PDT, "as escolhas de lideranças passaram a ser mais... quando o partido está no governo, passaram a ser mais por essa afetividade do candidato com o governo" (Entrevista realizada em 6/5/2010). Segundo o assessor do PR, essa "afetividade" do líder com o governo é medida por sua habilidade em obter a liberação de verba:

A liberação das emendas, que são um ponto principal, que é o combustível pra alimentar a satisfação dos deputados [...] Tanto que um dos principais trabalhos que é feito dentro da Liderança é isso, é o acompanhamento semanal pra ver "Tá liberando? Não tá? Tá empenhando? Não tá?" (Entrevista realizada em 9/4/2010).

Por exemplo, consoante o assessor do partido, o deputado Fernando Gabeira, líder natural do PV, não vinha comandando a bancada daquele partido na Câmara devido a suas "posições claramente antagônicas ao governo Lula em diversas áreas" (Entrevista realizada em 14/4/2004).

O poder que o governo exerce sobre as estruturas da Câmara dos Deputados, notadamente sobre as bancadas e as lideranças partidárias, inclusive de oposição, restou patenteado na análise comparada dos processos do PL n. 1.210/2007, da reforma política, e da PEC n. 511/2006, das medidas provisórias. Constatou-se ali que as bancadas partidárias, independentemente de seu posicionamento no espectro ideológico clássico ou em relação ao governo, comportaram-se internamente de modo mais coeso e mais articulado entre si no processo da PEC n. 511/2006 do que no do PL n. 1.210/2007, porque no primeiro processo legislativo, em que se pretendia pôr algum limite no poder do presidente da República de controlar a pauta das Casas do Congresso Nacional e, portanto, havia claro interesse do governo em jogo, este interveio vigorosamente. Nas bancadas governistas, essa intervenção se deu basicamente por meio das estruturas de liderança; nas bancadas de oposição, sobretudo na do DEM, diretamente, cooptando deputados personalistas, dependentes do governo.

Este trabalho, contudo, não se propôs a explicar/compreender somente a influência, sobre o comportamento da atual legislatura, do sistema eleitoral-partidário, notadamente o proporcionalismo de lista aberta, combinado com o sistema presidencialista de governo, em inter-relação com o poder de agenda do presidente da República, combinado com a centralização das atividades da Câmara nas mãos dos líderes partidários. Pretendeu explicar/compreender, igualmente, as ações dos deputados tendentes a reproduzir ou transformar esse estado de coisas. Aliás, foi sobretudo por meio da explicação/compreensão destas últimas ações que se buscou explicar/compreender a influência, sobre o comportamento parlamentar, daquelas combinações institucionais inter-relacionadas. 
Como já se observou, o PL n. 1.210/2007 representou a mais importante tentativa de alteração das regras políticas na $53^{\mathrm{a}}$ Legislatura. As lideranças das bancadas do PCdoB, do PT, do PPS, do PSOL, do PMDB, do PSDB e do DEM no começo se posicionaram a favor da reforma política proposta. O PCdoB, o PT e o PSDB inclusive fecharam questão nesse sentido. Já as lideranças das bancadas do PDT, do PSB, do PV, do PP, do PR, do PSC e do PTB desde o início eram contrárias. No caso específico do PDT, restou claro que havia uma diferença de posição entre a direção nacional do partido e sua bancada na Câmara, inclusive seu então líder, deputado Miro Teixeira. De acordo com o assessor do PDT, a direção nacional do partido era favorável aos principais itens da reforma política. Na contramão, o próprio deputado Miro Teixeira declarou ter disputado a liderança da bancada do PDT em 2007 com o objetivo de obstruir a reforma: "Eu disputei a liderança esse ano para trabalhar contra isso que se denominou de reforma política e não é nenhuma reforma política” (Entrevista realizada em 6/5/2010).

Com o início da discussão no Plenário, influenciado pelo grupo paulista o PSDB mudou de posição. O partido chegou até mesmo a outra vez fechar questão, daquela feita contra a reforma proposta. As lideranças tucanas se convenceram que as regras políticas vigentes de algum modo seriam mais favoráveis à formação de uma base de apoio à candidatura de José Serra a presidente da República. Alguns deputados do PSDB de outras regiões do país, entretanto, mantiveram-se favoráveis à reforma. Ao mesmo tempo, as lideranças do PP, do PR e do PTB, com a conivência da liderança do PMDB, crescentemente tensionada pelo grupo do Rio de Janeiro, comandado pelo deputado Eduardo Cunha, contrárias à reforma pressionavam o governo. Conforme relatou o deputado Ronaldo Caiado, do DEM, esses líderes partidários, em reunião com presidente da Câmara, ameaçaram deixar a base governista ou votar a favor das CPIs se o governo viesse a apoiar a reforma política proposta por meio do PL $\mathrm{n}$. 1.210/2007, fato igualmente testemunhado pelo deputado Raul Henry, do PMDB. Com a mudança de posição do PSDB e com a crescente pressão do PP, do PR, do PTB e do grupo do Rio, os líderes do PSB e do PMDB ao final liberaram as bancadas. Resultado: a lista fechada foi rejeitada e com ela foi virtualmente arquivada a reforma.

Eis aí a expressão máxima da influência do sistema político sobre o comportamento parlamentar: partidos fracos, com pouca capilaridade social, identidade ideológico-programática e coesão, constituídos de políticos individualistas, particularistas, apartidários e governistas, bem adaptados, portanto, às regras políticas vigentes, não querem e dificilmente poderiam mudá-las.

Já no caso da PEC n. 511/2006, a principal tentativa da 53ª Legislatura (20072011) de pôr algum limite ao poder legiferante do presidente da República e assim equilibrar as relações entre o Legislativo e o Executivo, ficou evidente que o governo é a principal força mobilizadora das estruturas da Câmara dos Deputados. Diferentemente do processo do PL n. 1.210/2007, em que o governo não interferiu ao 
menos abertamente, no processo de apreciação da PEC n. 511/2006, desde o começo da discussão no Plenário as bancadas partidárias se comportaram internamente de maneira mais coesa e mais articulada entre si: de um lado, as bancadas governistas, em geral mais congruentemente a favor do substitutivo da Comissão Especial, da lavra do deputado Leonardo Picciani, do grupo do Rio, que ampliava o controle do presidente da República sobre a pauta das Casas do Congresso Nacional, e contra os destaques das bancadas de oposição, que pretendiam podar-lhe os excessos, e, de outro lado, as bancadas de oposição, menos consistentemente contra os excessos do substitutivo. Irritado com a falha de seus líderes na Câmara, inclusive do então presidente Arlindo Chinaglia, em haver pautado uma matéria que era do interesse da oposição, o governo não mediu esforços para rapidamente fazer aprovar um texto que lhe favorecesse.

Assim, em que pese à fraqueza dos partidos e das lideranças partidárias, indubitavelmente a ingovernabilidade não figura entre os efeitos do sistema político adotado no Brasil. Resta saber, entretanto, se o preço pago - a excessiva concentração de poderes legislativos nas mãos do presidente da República e o consequente aviltamento do Congresso Nacional - é compatível com a democracia.

NOTAS

1 Financiamento de programas governamentais cujos benefícios são circunscritos a uma área particular, mas cujos custos são distribuídos a todos os contribuintes.

2 À medida que um dos termos da dicotomia estrutura/agência é tomado como elemento explicativo do outro, o pensamento social clássico e contemporâneo pode ser, grosso modo, dividido em dois conjuntos de perspectivas teóricas: de um lado, o conjunto de perspectivas objetivistas e estruturalistas, que, a despeito de discordarem sobre questões como a importância do consenso ou conflito no fluxo da vida social, centram sua análise nas coerções exercidas pelas estruturas sociais sobre a conduta dos atores individuais, caracterizando as propriedades de tais arranjos sociais como operando à revelia da vontade dos indivíduos; de outro lado, o conjunto de abordagens subjetivistas e individualistas, que focam nas diversas orientações subjetivas e procedimentos práticos de conduta intencionalmente mobilizados pelos indivíduos na produção da ação e da interação social, concebendo a ordem societária e suas instituições mais amplas como produtos contínuos e contingencialmente modificáveis das ações de tais agentes reflexivos.

Para Habermas (1988 [1967]), Bourdieu (2001) e Giddens (1986 [1984]), entretanto, essa dicotomização tem causado enormes prejuízos ao desenvolvimento da teoria social. Entendem esses autores, cada um a sua maneira, que um esforço de síntese teórica capaz de articular o plano das estruturas coletivas - dos padrões institucionalizados de conduta ou de relações que atuam coercitivamente sobre a formação/socialização e sobre a contínua ação dos 
agentes individuais, estendendo-se pelas coordenadas tempo-espaciais mais amplas que conformam grupos ou sociedades inteiras e transcendendo as existências individuais - com o plano da ação - da conduta individual cotidiana e de seus motores subjetivos - é necessário à explicação/compreensão mais acurada da vida societária (cf. PINTO, 2013).

3 Certos assessores das Lideranças Partidárias têm acesso a informações reservadas. Além de participarem das conversas e negociações envolvendo os respectivos líderes e demais membros das respectivas bancadas partidárias, participam também das reuniões reservadas que o presidente da Câmara costuma manter com os vários líderes em seu gabinete para definir a agenda mensal, ordem do dia e estratégias de votação. Seu recrutamento e permanência na função dependem do grau de confiabilidade que os líderes e demais membros das bancadas neles depositam. Não falariam, portanto, senão sob a condição de anonimato.

4 Deputado Fernando Coruja, então líder da bancada do PPS: "Nós temos uma situação sui generis. O nosso partido é um partido de esquerda. Nós saímos do governo Lula e nós passamos... Evidentemente que, do ponto de vista de extrema lógica, não podemos ter sintonia fina com os democratas. Mas do ponto de vista de um grupo de oposição, aí a sintonia existe” (Entrevista realizada em 28/4/2010).

5 O PSOL, na verdade, assumia uma posição de independência em relação tanto ao governo quanto à oposição liderada pelo PSDB.

6 Cf. PINTO, 2011, p. 21-96.

7 A despeito da denominação, emenda aglutinativa é, na verdade, uma técnica de votação. Por isso mesmo, diferentemente das demais emendas (supressivas, aditivas e modificativas), é apresentada na fase de votação, não podendo, portanto, incluir matéria nova. Trata-se de uma fusão de diversos textos (proposição original, proposições apensadas, emendas etc.) pendentes de votação com vistas a facilitar a aprovação da matéria. Quando ela envolve todos os textos pendentes de votação, é denominada emenda aglutinativa substitutiva global.

8 (Não) coeso, (in)congruente, (in)consistente e suas variações são termos empregados neste trabalho para qualificar o comportamento das bancadas partidárias na proposição, emendamento, discussão e votação de matérias (cf. nota de rodapé n. 14).

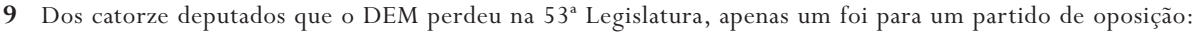
o PSDB.

10 Dos oito deputados que o PSDB perdeu naquela legislatura, apenas um foi para outro partido de oposição: o PPS.

11 Para maiores detalhes, cf. PINTO, 2011, p. 101-154.

12 Fato ainda mais curioso: o então advogado-geral da União, hoje ministro do STF, Dias Toffoli, representando o presidente da República no processo em tramitação no STF, defendeu a decisão do presidente da Câmara e requereu a denegação da segurança.

13 Com as quais se alinhava a bancada independente do PSOL.

14 Para maiores detalhes, $c f$. PINTO, 2011, p. 155-198.

15 Percentagem não desprezível, considerando que o máximo de incongruência a que uma bancada pode chegar em uma votação "sim" ou "não" é de 50\%. Por exemplo, no processo de apreciação do PL n. 1.210/2007, a bancada do PPS, que inicialmente era favorável à reforma política proposta, vinha apresentando os seguintes índices de incongruência nas votações nominais: $9 \%, 31 \%$ e $50 \%$. Na última votação, a da lista fechada, ocasião em que o líder a liberou, a bancada do PPS apresentou um índice de 60\%. Na verdade, a bancada, em sua maioria, mudou de posição em relação à reforma proposta: de favorável a contrária. No caso, o índice de incongruência da bancada do PPS, em seu novo posicionamento - contrário à reforma - foi de $40 \%$. 


\section{REFERÊNCIAS BIBLIOGRÁFICAS}

AMES, Barry. The deadlock of democracy in Brazil: interests, identities and institutions in comparative perspective. Ann Arbor: The University of Michigan Press, 2000.

ARAÚJO, Caetano E. P. Reforma política: desenho de um debate. In: MESSENBERG, Débora; PINTO, Júlio R. S. et al (Orgs.). Estudos legislativos: pensamento e ação política. Brasília: Câmara dos Deputados, Senado Federal; UnB, 2008. p. 55-70.

BOURDIEU, Pierre. Science de la science et réflexivité. Paris: Raisons d'Agir, 2001.

BRASIL. Câmara dos Deputados. Projeto de Lei n. 1.210, de 2007. Dispõe sobre as pesquisas eleitorais, o voto de legenda em listas partidárias preordenadas, a instituição de federações partidárias, o funcionamento parlamentar, a propaganda eleitoral, o financiamento de campanha e as coligações partidárias, alterando a Lei n. 4.737, de 15 de julho de 1965 (Código Eleitoral), a Lei n. 9.096, de 19 de setembro de 1995 (Lei dos Partidos Políticos) e a Lei n. 9.504, de 30 de setembro de 1997 (Lei das Eleições). Disponível em: $<$ http: / / www.camara.gov.br/proposicoesWeb/fichadetramitacao?idProposicao=353741>. Acesso em: 10 jul. 2010.

. Câmara dos Deputados. Proposta de Emenda à Constituição n. 511, de 2006. Estabelece que a Medida Provisória só terá força de lei depois de aprovada a sua admissibilidade pelo Congresso Nacional, sendo o início da apreciação alternado entre a Câmara e o Senado. Disponível em: <http://www.camara.gov.br/ proposicoesWeb/fichadetramitacao?idProposicao=313951>. Acesso em: 10 jul. 2010.

FIGUEIREDO, Argelina C.; LIMONGI, Fernando G. P. Executivo e Legislativo na nova ordem constitucional. Rio de Janeiro: FGV Editora, 1999.

GIDDENS, Anthony. (1984). The constitution of society: outline of the theory of structuration. Berkeley: University of California Press, 1986.

HABERMAS, Jürgen. (1967). On the logic of the social sciences. Cambridge, MA: The MIT Press, 1988.

MAINWARING, Scott. Presidentialism, multipartism, and democracy: the difficult combination. Comparative Political Studies, v. 26, n. 2, p. 198-228, 1993.

; TORCAL, Mariano. Teoria e institucionalização dos sistemas partidários após a terceira onda de democratização. Opinião Pública, v. XI, n. 2, p. 249-286, 2005.

PINTO, Júlio R. S. Poder Legislativo brasileiro: institutos e processos. Rio de Janeiro: Forense, 2009. Sistema político e comportamento parlamentar. Brasília: Consulex, 2011.

. O problema da relação estrutura/agência na teoria social e a possibilidade de convergência entre

Habermas e Bourdieu. Temática, ano 21, n. 41, p. 197-217, 2013.

Júlio Roberto de Souza Pinto

Brasília - DF - Brasil
julio.pintolacamara.leg.br

Júlio Roberto de Souza Pinto
Advogado.
Doutor em Sociologia Pela Universidade de Brasília.
Professor do Mestrado em Poder Legislativo
da CÂmara dos Deputados.
do Norte, EUA, de 2014 a 2015) e da Universidade
De Oxford (Reino Unido, de 2010 a 2011).


